\title{
Origin of B chromosomes in the genus Astyanax (Characiformes, Characidae) and the limits of chromosome painting
}

\author{
Duílio M. Z. de A. Silva ${ }^{1}$ Sandro Natal Daniel ${ }^{2} \cdot$ Juan Pedro M. Camacho ${ }^{3}$. \\ Ricardo Utsunomia $^{1}$ - Francisco J. Ruiz-Ruano ${ }^{3}$ - Manolo Penitente ${ }^{2}$. \\ José Carlos Pansonato-Alves $^{1} \cdot$ Diogo Teruo Hashimoto $^{4} \cdot$ Claudio Oliveira $^{1}$. \\ Fábio Porto-Foresti ${ }^{2} \cdot$ Fausto Foresti $^{1}$
}

Received: 14 December 2015 / Accepted: 2 March 2016 / Published online: 16 March 2016

(C) Springer-Verlag Berlin Heidelberg 2016

\begin{abstract}
Eukaryote genomes are frequently burdened with the presence of supernumerary (B) chromosomes. Their origin is frequently investigated by chromosome painting, under the hypothesis that sharing the repetitive DNA sequences contained in the painting probes is a sign of common descent. However, the intragenomic mobility of many anonymous DNA sequences contained in these probes (e.g., transposable elements) adds high uncertainty to this conclusion. Here we test the validity of chromosome painting to investigate $\mathrm{B}$ chromosome origin by comparing its results for seven B chromosome types in two fish species genus Astyanax, with those obtained (1) by means of the physical mapping of $18 \mathrm{~S}$ ribosomal DNA (rDNA), H1 histone genes, the As51 satellite DNA and the (AC) 15 microsatellite, and (2) by comparing the nucleotide sequence of one of these families (ITS regions from ribosomal DNA) between genomic DNA from B-lacking individuals in both
\end{abstract}

Communicated by J. Cerdá.

Electronic supplementary material The online version of this article (doi:10.1007/s00438-016-1195-y) contains supplementary material, which is available to authorized users.

Duílio M. Z. de A. Silva

duilio@ibb.unesp.br

1 Departamento de Morfologia, Instituto de Biociências, Universidade Estadual Paulista, Distrito de Rubião Junior, s/n, Botucatu, SP 18618-970, Brazil

2 Departamento de Ciências Biológicas, Faculdade de Ciências, Universidade Estadual Paulista, Campus de Bauru., Bauru, SP 17033-360, Brazil

3 Departamento de Genética, Universidad de Granada, 18071 Granada, Spain

4 CAUNESP, Universidade Estadual Paulista, Campus Jaboticabal, Jaboticabal, SP 14884-900, Brazil species and the microdissected DNA from two metacentric B chromosomes found in these same species. Intra- and inter-specific painting suggested that all $\mathrm{B}$ chromosomes that were assayed shared homologous DNA sequences among them, as well as with a variable number of A chromosomes in each species. This finding would be consistent with a common origin for all seven B chromosomes analyzed. By contrast, the physical mapping of repetitive DNA sequences failed to give support to this hypothesis, as no more than two B-types shared a given repetitive DNA. Finally, sequence analysis of the ITS regions suggested that at least some of the B chromosomes could have had a common origin.

Keywords B chromosome - rDNA - Satellite DNA · Microsatellites $\cdot$ Chromosome painting

\section{Introduction}

In addition to the chromosomes of the standard (A) complement, approximately $15 \%$ of the eukaryotic organisms harbor supernumerary elements called B chromosomes. They are mainly composed of repetitive DNA sequences such as multigene families, satellite DNAs and mobile elements (Camacho 2005), although a few examples of protein coding genes have been described recently (see Martis et al. 2012; Klemme et al. 2013; Trifonov et al. 2013; Valente et al. 2014). B chromosomes may arise from the A chromosomes of their current host species (intraspecific origin) or else may result from hybridization processes (interspecific origin) (Perfectti and Werren 2001; Camacho 2005; Houben et al. 2013). It has been suggested that B chromosomes can intra-specifically originate in the ancestor of a species group and surpass cladogenetic events 
(Moreira-Filho et al. 2001). Conversely, B chromosomes can originate in a species and move to other closely relative species through introgression (Tosta et al. 2014). The latter was inferred from the scarce sequence variations found for a SCAR marker present in the B chromosomes of several bee species of the genus Partamona. This shows that the analysis of B chromosomes in several closely related species can be very informative about B chromosome origins.

Astyanax Baird \& Girard is a specious fish genus, currently composed of 154 valid species within the family Characidae (Eschmeyer 2015), with a distribution area ranging from the southern United States to central Argentina (Ornelas-García et al. 2008). The extensive chromosome diversity found between populations of A. fasciatus, A. scabripinnis, and A. altiparanae has led some authors to consider them as 'species complexes' (Moreira-Filho and Bertollo 1991; Artoni et al. 2006; Castro et al. 2015) because it is sometimes difficult to establish whether two populations of morphologically similar individuals actually share a common genic pool or whether they belong to different cryptic species (Pansonato-Alves et al. 2013; Castro et al. 2015). Consequently, several cytogenetic studies have shown a remarkable karyotype diversification in this group, including different diploid numbers, hybrid cytotypes and differential intra-genomic spread of repetitive DNAs (Moreira-Filho and Bertollo 1991; Mantovani et al. 2005; Pazza et al. 2006; Vicari et al. 2008; Kavalco et al. 2012; Silva et al. 2013; Castro et al. 2014). Moreover, the occurrence of several types of B chromosomes differing in morphology, size and banding patterns has also been reported (Moreira-Filho et al. 2004; Fernandes and Martins-Santos 2005; Carvalho et al. 2008; Hashimoto et al. 2008; Oliveira et al. 2009; Santos et al. 2013; Daniel et al. 2015).

The most frequent B-type in Astyanax is a large metacentric chromosome (Moreira-Filho et al. 2004). In A. scabripinnis, it shows a symmetric location of a satellite DNA named As51 in both arms (here we will call it BsM). This fact, along with meiotic pairing of the two arms, constitutes the main evidence for its isochromosome nature (Vicente et al. 1996, Mestriner et al. 2000, Vicari et al. 2011). Likewise, Silva et al. (2014) hypothesized the isochromosome nature of another metacentric B macrochromosome found in A. paranae because of the symmetric location of two repetitive DNAs (i.e., H1 histone genes and $18 \mathrm{~S}$ ribosomal DNA sites). Although achieving resolution, those studies were carried out in few, or unique, populations of a single species, but analyses concerning several B-types in different Astyanax species are scarce and based only on classical cytogenetic data (Hashimoto et al. 2011). Therefore, the use of more informative techniques, such as chromosome painting, the physical mapping of repetitive DNAs such as 18S rDNA, histone genes, satellite DNAs and microsatellites, and even sequence comparisons, is necessary to test the possibility that some of these B chromosome variants might have had a common origin, as previously suggested (Moreira-Filho et al. 2001).

To test this hypothesis, we performed intra- and interspecific chromosome painting with DNA probes obtained from four B chromosome variants from three species, as well as physical mapping of four types of repetitive DNA sequences; i.e., 18S rDNA, H1 histone genes, the As51 satellite DNA and the $(\mathrm{AC})_{15}$ microsatellite. In addition, partial ITS-rDNA nucleotide sequences comparisons between B-lacking genomic DNA and B chromosome microdissected DNA was already performed.

\section{Materials and methods}

\section{Origin of samples and karyotype analysis}

Six distinct samples were analyzed, including three different species (Table 1). From these, B chromosomes were already described in two samples, including A. bockmanni and A. paranae (Daniel et al. 2012; Silva et al. 2014), but not in the population of A. fasciatus from the Mogi-Guaçu river basin (Pazza et al. 2008; Kavalco et al. 2012). After analysis, specimens were deposited at the fish collection of the Laboratório de Biologia e Genética de Peixes (LBP) at UNESP, Botucatu, São Paulo, Brazil, under the vouchers LBP15262 (A. bockmanni-Água da Madalena stream), LBP19574 (A. fasciatus-Água da Madalena stream), LBP19573 (A. fasciatus-Córrego da Araras stream) and LBP13340 (A. paranae-Água da Madalena stream). The specimens from the Alambari river (A. bockmanni and A. fasciatus) were deposited at the fish collection of the Laboratório de Genética de Peixes at UNESP, Bauru, São Paulo, Brazil.

\section{Sampling and mitotic chromosome collection}

Mitotic chromosomes were obtained following the protocol established by Foresti et al. (1981). The nucleolus organizer regions (NORs) were detected with silver nitrate impregnation (Howell and Black 1980). The chromosome morphology was determined in accordance with the arm ratio (Levan et al. 1964), and the chromosomes were classified as metacentric (m), submetacentric (sm), subtelocentric (st) and acrocentric (a) and were arranged in the karyotype in decreasing order of size.

\section{Chromosome microdissection}

Microdissection was performed in an Eppendorf TransferMan NK2 micromanipulator coupled to a Zeiss Axiovert 100 microscope. About ten copies of each B chromosome 
Table 1 Collection sites, number of specimens, B chromosomes features and number of individuals with B chromosomes in Astyanax populations, where $\mathrm{M}$ metacentric, A acrocentric, ST subtelocentric

\begin{tabular}{|c|c|c|c|c|c|c|c|c|c|c|c|c|}
\hline Species & Waterway & River basin & Coordinates & Specimens & B-type & B name & Female & & Male & & Undefined & \\
\hline & & & & & & & OB & 1B & OB & 1B & OB & 1B \\
\hline \multirow[t]{2}{*}{ A. bockmanni } & $\begin{array}{l}\text { Água da } \\
\text { Madalena } \\
\text { stream }\end{array}$ & Paranapanema & $\begin{array}{l}22^{\circ} 59^{\prime} 23^{\prime \prime} \mathrm{S} \\
48^{\circ} 25^{\prime} 31^{\prime \prime} \mathrm{W}\end{array}$ & 13 & Large M & $\mathrm{BbM}$ & 8 & 3 & 2 & & & \\
\hline & $\begin{array}{l}\text { Alambari } \\
\text { river }^{\mathrm{a}}\end{array}$ & & $\begin{array}{l}22^{\circ} 27^{\prime} 6^{\prime \prime} \mathrm{S} \\
49^{\circ} 14^{\prime} 25^{\prime \prime} \mathrm{W}\end{array}$ & 44 & Small A & $\mathrm{Bba}$ & 19 & 2 & 18 & 5 & & \\
\hline \multirow[t]{4}{*}{ A. fasciatus } & $\begin{array}{l}\text { Água da } \\
\text { Madalena } \\
\text { stream }\end{array}$ & & $\begin{array}{l}22^{\circ} 59^{\prime} 23^{\prime \prime} \mathrm{S} \\
48^{\circ} 25^{\prime} 31^{\prime \prime} \mathrm{W}\end{array}$ & 23 & Large M & BfMa & & & 1 & 2 & 12 & 6 \\
\hline & & & & & Medium SM & Bfsm & & 1 & & & & 1 \\
\hline & Alambari river & & $\begin{array}{l}22^{\circ} 27^{\prime} 6^{\prime \prime} \mathrm{S} \\
49^{\circ} 14^{\prime} 25^{\prime \prime} \mathrm{W}\end{array}$ & 12 & Medium ST & Bfst & 6 & 2 & 2 & 2 & & \\
\hline & $\begin{array}{l}\text { Córrego das } \\
\text { Araras } \\
\text { stream }\end{array}$ & Mogi-Guaçu & $\begin{array}{l}22^{\circ} 22^{\prime} 43^{\prime \prime} \mathrm{S} \\
47^{\circ} 25^{\prime} 37^{\prime \prime} \mathrm{W}\end{array}$ & 14 & Large M & $\mathrm{BfMb}$ & & & 5 & 1 & 7 & 1 \\
\hline A. paranae & $\begin{array}{l}\text { Capivara } \\
\text { river }^{\mathrm{b}}\end{array}$ & Tietê & $\begin{array}{l}22^{\circ} 53^{\prime} 57^{\prime \prime} \mathrm{S} \\
48^{\circ} 23^{\prime} 11^{\prime \prime} \mathrm{W}\end{array}$ & 50 & Large M & BpM & 20 & 12 & 17 & 1 & & \\
\hline
\end{tabular}

a Daniel et al. (2012)

b Silva et al. (2014)

were microdissected from each sample. The following supernumeraries were microdissected and included: i) the large metacentric found in A. paranae from Capivara river (BpM); ii) the large metacentric found in A. fasciatus from Água da Madalena stream (BfMa); iii) the medium subtelocentric found in A. fasciatus from Alambari river (Bfst); and iv) the small acrocentric found in A. bockmanni from Alambari river (Bba). The microdissected DNAs were placed in $9 \mu \mathrm{l}$ of DNase free ultrapure water and then amplified using the GenomePlex Single Cell Whole Genome Amplification Kit (WGA4-Sigma) (Gribble et al. 2004). After the initial amplification, we generated DNA probes labeled with digoxigenin-11-dUTP (Roche Applied Science) using the GenomePlex Whole Genome Amplification Reamplification Kit (WGA3-Sigma) following the manufacturer's protocol.

\section{DNA amplification, cloning and sequencing}

For all gDNA extractions, we used the Wizard Genomic DNA Purification Kit (Promega) following manufacturer's instructions. Partial ITS (Internal Transcribed Spacer of rDNA) sequences were obtained by PCR (Polymerase Chain Reaction) from A. paranae and A. fasciatus genomic DNA (gDNA), obtained from B-lacking individuals, using the primers SBR (5'-GTAGGTGAACCTGCAGAAGG-3') and JM5 (5'-TACCGGCCTCACACCGTCC-3') (MontoyaBurgos 2003). The reactions were performed in $1 \times$ PCR buffer, $1.5 \mathrm{mM}$ of $\mathrm{MgCl} 2,200 \mathrm{mM}$ of each dNTP (dATP, dCTP, dGTP, dTTP), $0.5 \mathrm{U}$ of Taq polymerase (Invitrogen),
$0.1 \mathrm{mM}$ of each primer and $50 \mathrm{ng}$ of gDNA. The basic cycle to amplify these regions consisted of denaturation at $95{ }^{\circ} \mathrm{C}$ for $5^{\prime}$, followed by 30 cycles at $95{ }^{\circ} \mathrm{C}$ for $1^{\prime}, 45^{\prime \prime}$ at $54{ }^{\circ} \mathrm{C}$, $1^{\prime}$ at $72{ }^{\circ} \mathrm{C}$ and a final extension of $10^{\prime}$ at $72{ }^{\circ} \mathrm{C}$. We also amplified ITS sequences on the DNA from microdissected B chromosomes of A. fasciatus ( $\mu \mathrm{BfMa}$ ). To isolate a representative diversity of copies of these sequences present in the PCR reaction, we cloned the PCR obtained bands for these genes by linking them to a TOPO TA cloning vector and cloning them in One Shot TOP10 Competent Cells. A number of clones were chosen for DNA sequencing by the Sanger's method. We then isolated the plasmid DNA with the Perfectprep Plasmid Mini kit (Eppendorff). For all DNA sequences, the PCR products were purified using the ExoSAP-IT kit (USB Corporation) and were sequenced with the Big Dye TM Terminator v 3.1 Cycle Sequencing Ready Reaction Kit (Applied Biosystems), following manufacturer's instructions. We sequenced each plasmid in both directions using the M13F (5'-GTAAAACGACGGCCAG-3') and M13R (5'-CAGGAAACAGCTATGAC-3') primers.

\section{Repetitive DNA probes and FISH experiments}

Partial 18S rDNA and $\mathrm{H} 1$ histone probes was obtained by PCR directly from the genome of A. bockmanni using primers described previously (Hashimoto et al. 2011 and Utsunomia et al. 2016). The reactions were performed in 1X PCR buffer, $1.5 \mathrm{mM}$ of $\mathrm{MgCl} 2,200 \mathrm{mM}$ of each dNTP (dATP, dCTP, dGTP, and dTTP), $0.5 \mathrm{U}$ of Taq polymerase 
(Invitrogen), $0.1 \mathrm{mM}$ of each primer and $50 \mathrm{ng}$ of gDNA. The basic cycle to amplify these regions consisted of denaturation at $95^{\circ} \mathrm{C}$ for $5^{\prime}$, followed by 30 cycles at $95^{\circ} \mathrm{C}$ for $1^{\prime}, 45^{\prime \prime}$ at $54^{\circ} \mathrm{C}, 1^{\prime}$ at $72{ }^{\circ} \mathrm{C}$ and a final extension of $10^{\prime}$ at $72{ }^{\circ} \mathrm{C}$. $\mathrm{H} 1$ histone and $18 \mathrm{~S}$ rDNA probes were labeled with biotin-16-dUTP by PCR. An oligonucleotide probe containing the As51 satellite sequence obtained in Genbank database, U87962 (Mestriner et al. 2000) was labeled with digoxigenin-11-dUTP during synthesis by Sigma (St. Louis, MO, USA). Additionally, (AC) 15 microsatellite probes were also used and directly labeled with 6-Carboxytetramethyl Rhodamine (TAMRA) during synthesis by Sigma.

For FISH experiments, the chromosomes were treated according to the procedures described by Pinkel et al. (1986) using high stringency conditions. The probes were labeled by PCR with biotin-16-dUTP (Roche Applied Science), and the signal was detected with avidin-FITC (Roche Applied Science) or else they were labeled with digoxigenin-11-dUTP (Roche Applied Science), and the signal was detected with anti-digoxigenin-rhodamine (Roche Applied Science). The slides with the microsatellite hybridization solution were washed two times in $2 \times$ SSC for $5^{\prime}$ and in PBS $1 \times$ for $30^{\prime \prime}$ at room temperature, and the chromosomes were counterstained with DAPI, following the protocol established in Cioffi et al. (2011). From each individual, a minimum of 20 cells was analyzed to confirm the FISH results.

\section{Sequence analysis}

In addition to the sequences obtained in the present study, we used the ITS sequences obtained by Silva et al. (2014) in Astyanax species, which are available in GenBank under accession numbers KJ129693-KJ129719 (ITS1 sequence) and KJ129729- KJ129755 (ITS2 sequence). All DNA sequences were initially analyzed with Geneious version Pro 4.8.5 created by Biomatters (http://www.geneious. $\mathrm{com} /$ ). Sequence alignments were performed with the online version of Mafft software (Katoh and Standley 2013). DNA diversity analyses were performed with the DnaSP software (Librado and Rozas 2009). The Minimum Spanning Network (MSN) was performed in the PopART software (http://popart.otago.ac.nz).

In order to confirm their identity, the sequences were used as queries for BLASTn (Altschul et al. 1990) searches against NCBI's nr database (http://www.ncbi.nlm.nih.gov/ blast) and then were deposited in the GenBank with the following accession numbers: KU671238-KU671265 (ITS1 sequence), KU671266- KU671293 (ITS2 sequence). All sequences contaminated with ambient bacterial DNA were carefully screened and discarded. Statistical comparisons were performed in a spreadsheet program. The Student $t$ tests compared ITS1 and ITS2 nucleotide diversity values between $\mu \mathrm{BfMa}$ and $A$. fasciatus $0 \mathrm{~B}$-gDNA, A paranae 0B-gDNA and A. fasciatus $0 \mathrm{~B}-\mathrm{gDNA}$, and $\mu \mathrm{BpM}$ and $A$. paranae 0B-gDNA.

\section{Results}

\section{Chromosome analysis}

We include here the analysis of seven different $B$ chromosomes found in A. bockmanni (two B variants), A. fasciatus (four B variants) and A. paranae (a single B-type). Three of these B chromosomes were previously described by Daniel et al. (2012) and Silva et al. (2014), and the four remaining $\mathrm{B}$ chromosomes are reported here for the first time. Three A. bockmanni specimens from the Água da Madalena stream carried a large metacentric B chromosome (BbM), whereas seven individuals from the Alambari river carried a small acrocentric B chromosome (Bba). In A. fasciatus, eight specimens collected at the Água da Madalena stream carried a large metacentric B chromosome (BfMa), and two specimens carried a large submetacentric B chromosome (Bfsm). In this population, we found a variable number of A chromosomes: $2 n=45+B$ (six individuals), 46 (11 individuals), $46+B$ (two individuals), 47 (two individuals) and $47+B$ (two individuals). In addition, two A. fasciatus specimens collected at the Córrego das Araras stream carried large metacentric B chromosomes (BfMb), whereas four individuals from the Alambari river carried a medium sized subtelocentric B chromosome (Bfst). Finally, some $A$. paranae specimens carried a large metacentric $(\mathrm{BpM})$ previously described by Silva et al. (2014).

Chromosome painting experiments were performed with DNA probes obtained by microdissection of four of these B chromosomes. Intra-specific experiments showed that all four B-derived probes (Bba, BfM, Bfst and $\mathrm{BpM}$ ) painted the whole $\mathrm{B}$ chromosome length and some regions in several A chromosomes (Table 2 and Fig. 1). In addition, cross-species painting experiments revealed that all $\mathrm{B}$ chromosomes in the three species analyzed shared large amounts of DNA sequences and that the B-derived DNA sequences contained in the B-probes also hybridized at some A chromosome regions, especially in a metacentric pair of all three species. The number of $\mathrm{A}$ chromosomes painted was higher in intra- than interspecific experiments (Fig. 1; Table 3). However, the BpM probe cross-painted more A chromosomes in the genome of A. fasciatus from the Água da Madalena stream (carrying BfMa) than the intraspecific BfMa probe itself. Taken together, the chromosome painting experiments showed that all $\mathrm{B}$ chromosomes in these three species shared some DNA sequences. 
Table 2 Cross-species chromosome painting experiments results with B-specific probes of different Astyanax species, indicating the regions painted of each $\mathrm{B}$ chromosome

\begin{tabular}{lcccccc}
\hline B chromosome B probe & BbM & Bba & BfMa & Bfst & BfMb & BpM \\
\hline $\begin{array}{l}\text { Bba } \\
\text { BfMa }\end{array}$ & Full & & Proximal & Full & & \\
Bfst & & & & Full & Full & \\
BpM & Full & Full & Proximal & Full & Full & a \\
\hline
\end{tabular}

The blank spaces indicate experiments not performed

a Silva et al. (2014)

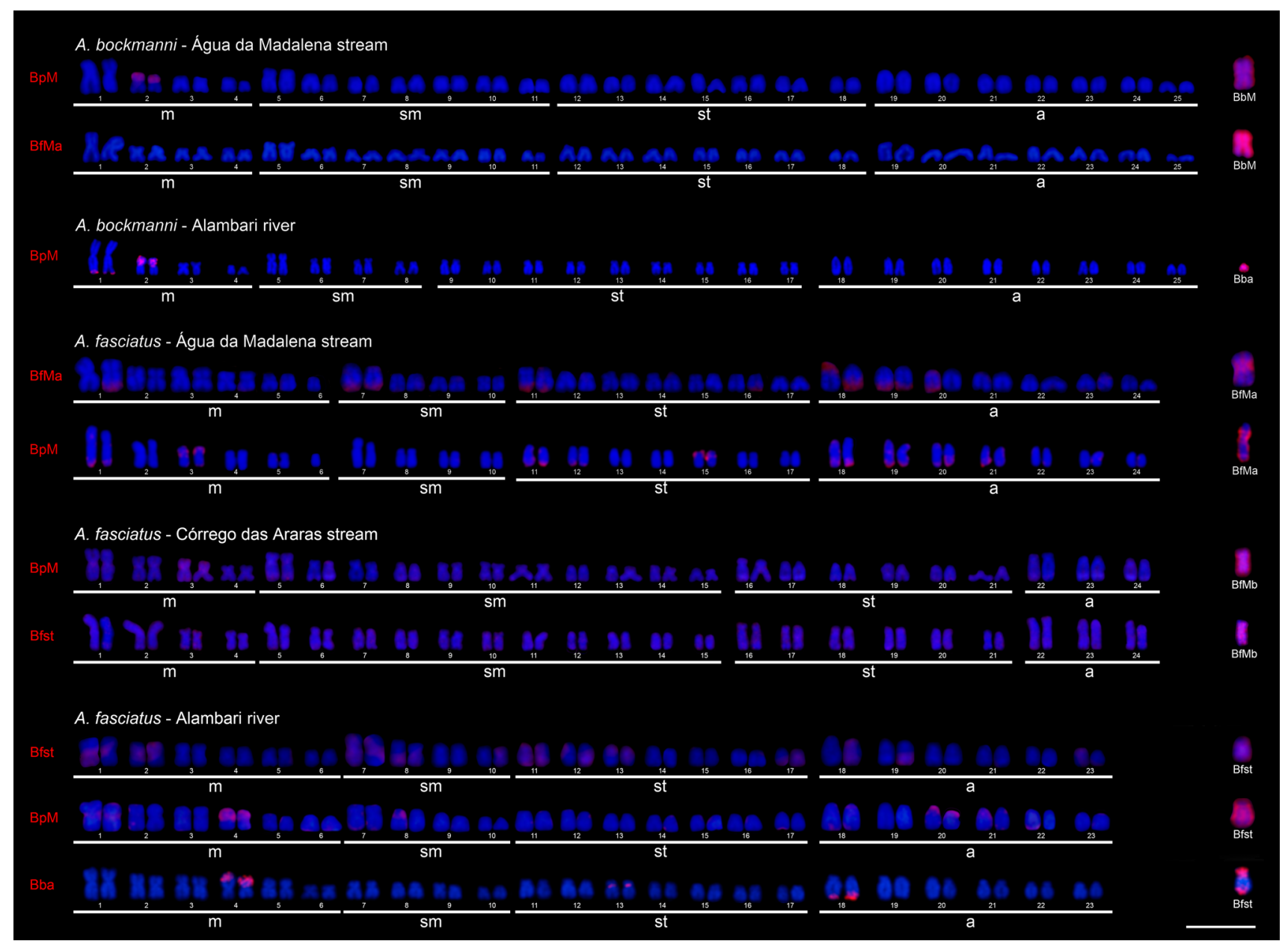

Fig. 1 Karyotypes of Astyanax species after chromosome painting with probes manufactured from microdissected B chromosomes of Astyanax populations. In the left, the names in red indicate the B

We also performed physical mapping for several repetitive DNA families, which showed that, of the seven B-types analyzed, only two metacentric B chromosomes carried $18 \mathrm{~S}$ rDNA on one (BfMa) or both (BpM) chromosome arms, the latter result being previously described by Silva et al. (2014) (Fig. 2). Remarkably, rDNA showed rather different patterns of rDNA distribution on the A chromosomes of the two species harboring these two B chromosome variants (A. fasciatus and A. paranae; Fig. 3). Silver chromosome used as a probe. The individual of $A$. fasciatus from the Água da Madalena stream had a diploid number of $2 n=47+$ B. Bar $10 \mu \mathrm{m}$ (color figure online)

nitrate impregnation showed that the rRNA gene clusters in BfMa were active (Fig. 3), but those in BpM were not (Silva et al. 2014).

Likewise, FISH performed with the H1 histone gene probe showed its presence in only two of the seven $B$ variants; i.e., on the short arm of the Bfst variant and pericentrically on both arms in the BpM type, the latter pattern being previously described by Silva et al. (2014) (Fig. 2). Even scarcer was the presence of the As51 satellite DNA 
Table 3 Cross-species chromosome painting experiments with $\mathrm{B}$-specific probes (Bba, BfMa, Bfst, BpM) of different Astyanax species, indicating the number of marked A chromosomes by population

\begin{tabular}{llcccc}
\hline Species & Population & Bba & BfMa & Bfst & BpM \\
\hline A. bockmanni & AM & & 0 & & 2 \\
& Al & & & & 4 \\
A. fasciatus & AM & & 10 & & 18 \\
& CA & & & 14 & 8 \\
& Al & 6 & & 20 & 5 \\
A. paranae & Ca & & & & $11^{\text {a }}$ \\
\hline
\end{tabular}

The blank spaces indicate experiments that were not performed

$A M$ Água da Madalena stream, $A l$ Alambari river, $C A$ Córrego das Araras stream, $\mathrm{Ca}$ Capivara river

${ }^{\text {a }}$ Extracted from Silva et al. (2014)

on B chromosomes because it was found only in the BfMa variant (Fig. 2). The reliability of this marker, however, was weakened by the extensive variation in chromosome distribution found between species and also between populations within species (Fig. 3).

By contrast, the (AC) ${ }_{15}$ microsatellite showed conspicuous clusters in all seven B chromosome variants analyzed (Fig. 2). They were located in both terminal regions of the $\mathrm{BpM}, \mathrm{BbM}$, Bfst and BfMb variants and in the full length of the Bba chromosome (Fig. 2). However, in the BfMa and Bfsm chromosomes, $(\mathrm{AC})_{15}$ microsatellite blocks were detected at interstitial locations in the long arm (co-located with the As51 satellite in the BfMa) and in a sub-terminal region on the short arm (Figs. 2, 4). This might point to a conceivable origin of Bfsm through partial deletions in both arms of the BfMa chromosome, one shortening the As51 lacking arm and the other leading to the loss of As51 in the other arm. In the A chromosomes of all three species, this microsatellite sequence was highly abundant as both conspicuous clusters and a spread pattern (Fig. S1). This genomic ubiquity of the $(\mathrm{AC})_{15}$ microsatellite makes it a poor marker for analyzing $\mathrm{B}$ chromosome origin. Taken together, the FISH results showed limited coincidences between $\mathrm{B}$ variants for the repetitive DNAs analyzed (Fig. 4).

\section{DNA sequence analysis}

We amplified ITS sequences from 0B-gDNA of A. paranae and A. fasciatus and from $\mu$ BfMa chromosome. For a more inclusive analysis, we also included the ITS sequences from $\mu$ BpM reported by Silva et al. (2014). In total, we analyzed $414 \mathrm{nt}$ in the ITS1 region and $373 \mathrm{nt}$ in the ITS2 one.

Haplotype analysis showed that each sequence was actually unique, except two sequences from B-lacking $A$. paranae being identical, thus constituting a same haplotype and two sequences from the BpM chromosome constituting another haplotype. A minimum spanning network (MSN), built with the $787 \mathrm{nt}$, showed three main groups of sequences (Fig. 5). One included all 10 DNA sequences coming from the BpM chromosome and 1 from the BfMa chromosome. At the other end of the MSN, a second group
Fig. 2 Different B chromosome variants of Astyanax species after FISH with $18 \mathrm{~S}$ rDNA, $\mathrm{H} 1$ histone, As51 satellite and (AC) ${ }_{15}$ microsatellite probes. *Illustration of a B chromosome described by Mestriner et al. (2000) and Vicari et al. (2011). $A M$ Água da Madalena stream, Al Alambari river, $C A$ Córrego das Araras stream, $\mathrm{Ca}$ Capivara river, $C P$ Córrego das Pedras river. Bar $10 \mu \mathrm{m}$
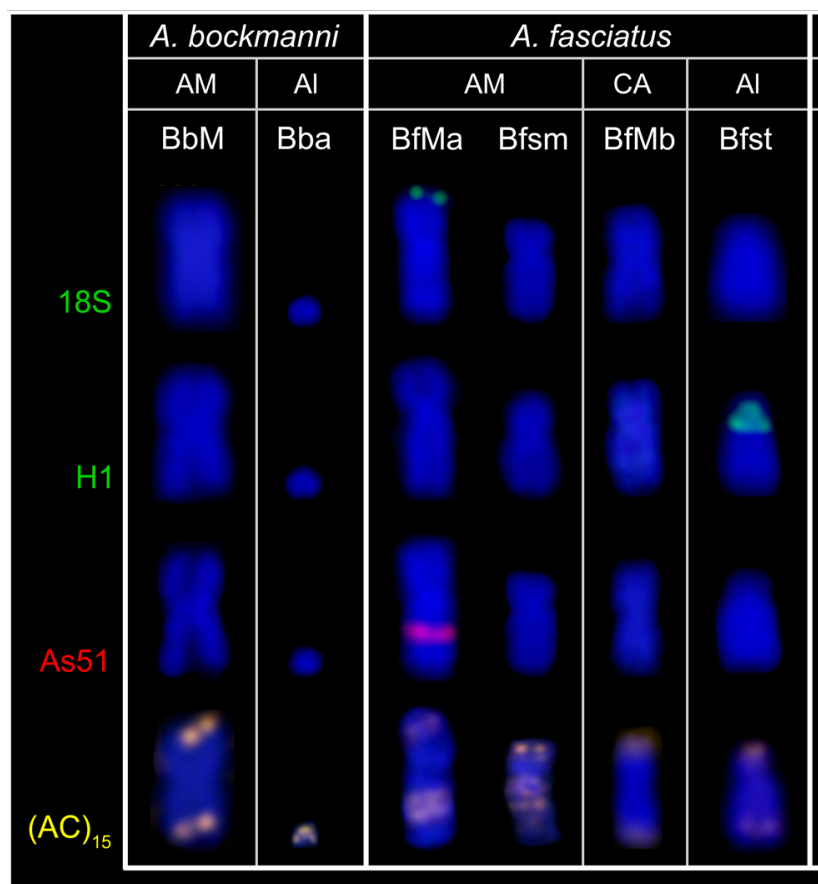

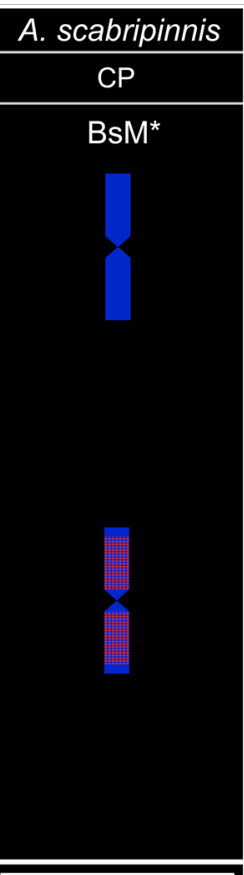




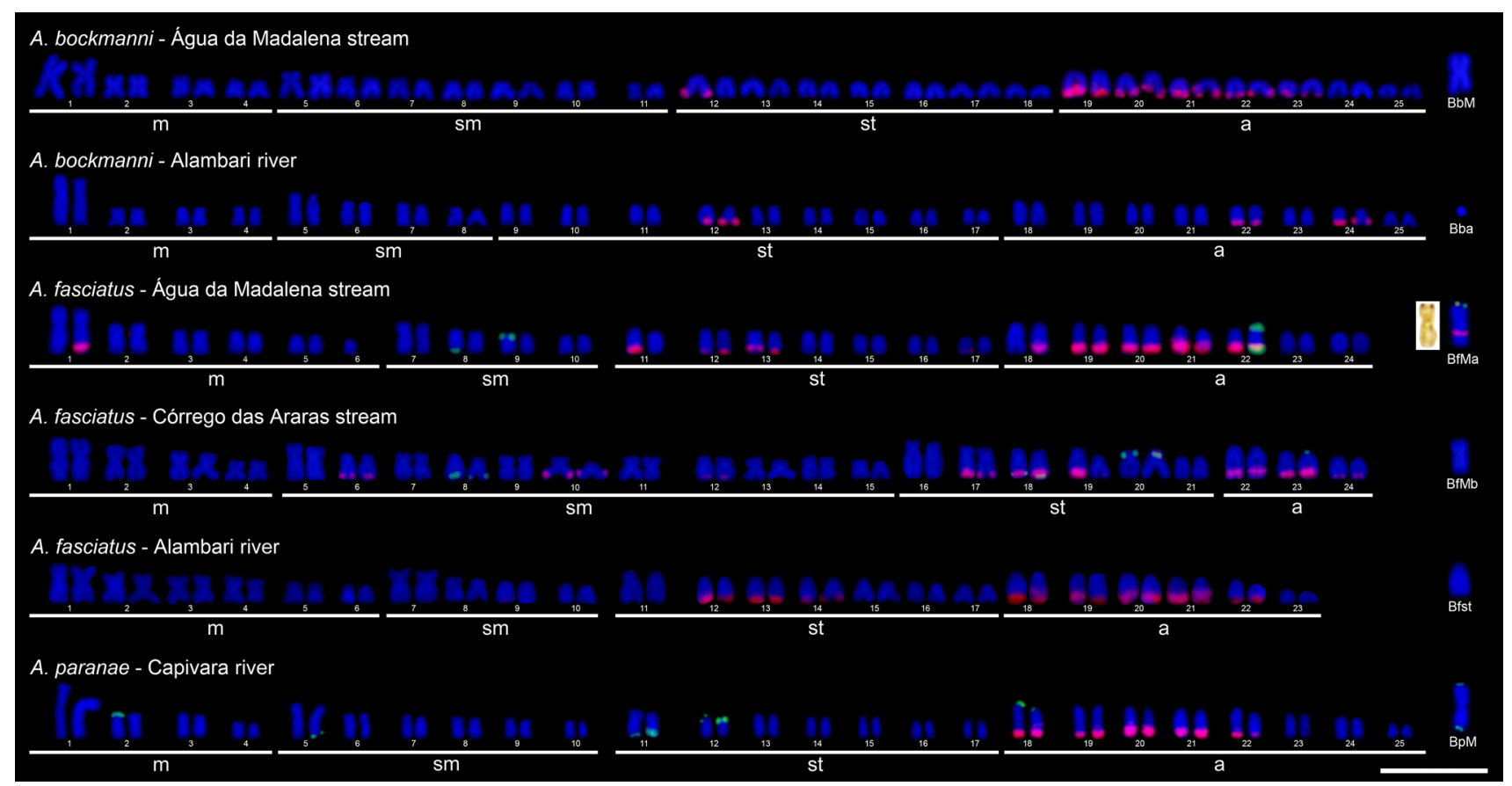

Fig. 3 Karyotypes of A. paranae from the Capivara river and A. fasciatus from the Água da Madalena stream and Córrego das Araras stream after FISH with the As51 satellite (red) and 18S rDNA (green) and karyotypes of A. fasciatus from the Alambari river and A. bockmanni from the Água da Madalena stream and Alambari river after
FISH with the As51 satellite (red) probe. The individual of A. fasciatus from the Água da Madalena stream had a diploid number of $2 n=47+B$. In the inset, the BfMa chromosome after silver nitrate staining. Bar $10 \mu \mathrm{m}$ (color figure online)
Fig. 4 Ideogram showing the location of repetitive DNA sequences in the B chromosomes variants of Astyanax populations. *Mestriner et al. (2000)

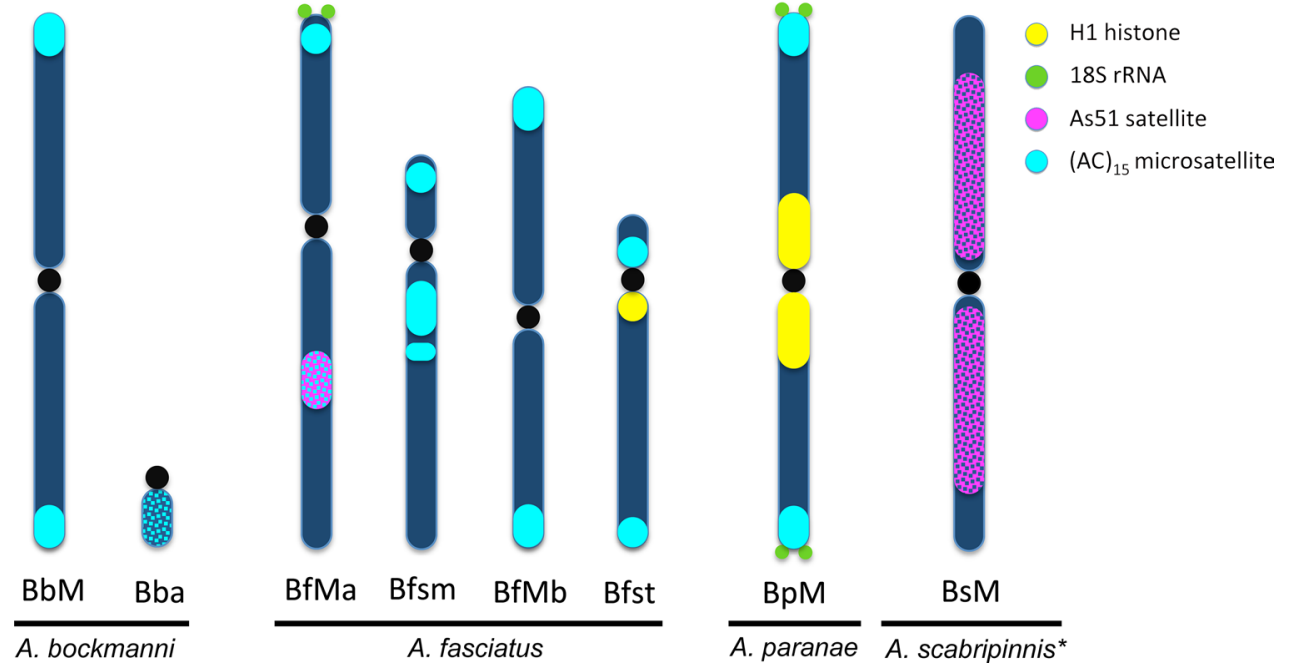

included 8 DNA sequences from B-lacking A. fasciatus and 1 from the BfMa chromosome. A third group included all 8 sequences from B-lacking A. paranae and 3 from B-lacking $A$. fasciatus, as well as 12 sequences from the BfMa chromosome. The latter group actually included a heterogeneous collection of ITS sequences being intermediate between the two other groups (Fig. 5).
Nucleotide diversity for the ITS1 sequences was similar for the 0B-gDNA of A. paranae and A.fasciatus and $\mu$ BfMa-DNA, but it was about four times lower in the $\mu$ BpM-DNA, suggesting higher homogenization for ITS1 sequences in the B chromosome from A. paranae. On the other hand, nucleotide diversity for the ITS2 sequences was about four times lower in 0B-gDNA from 


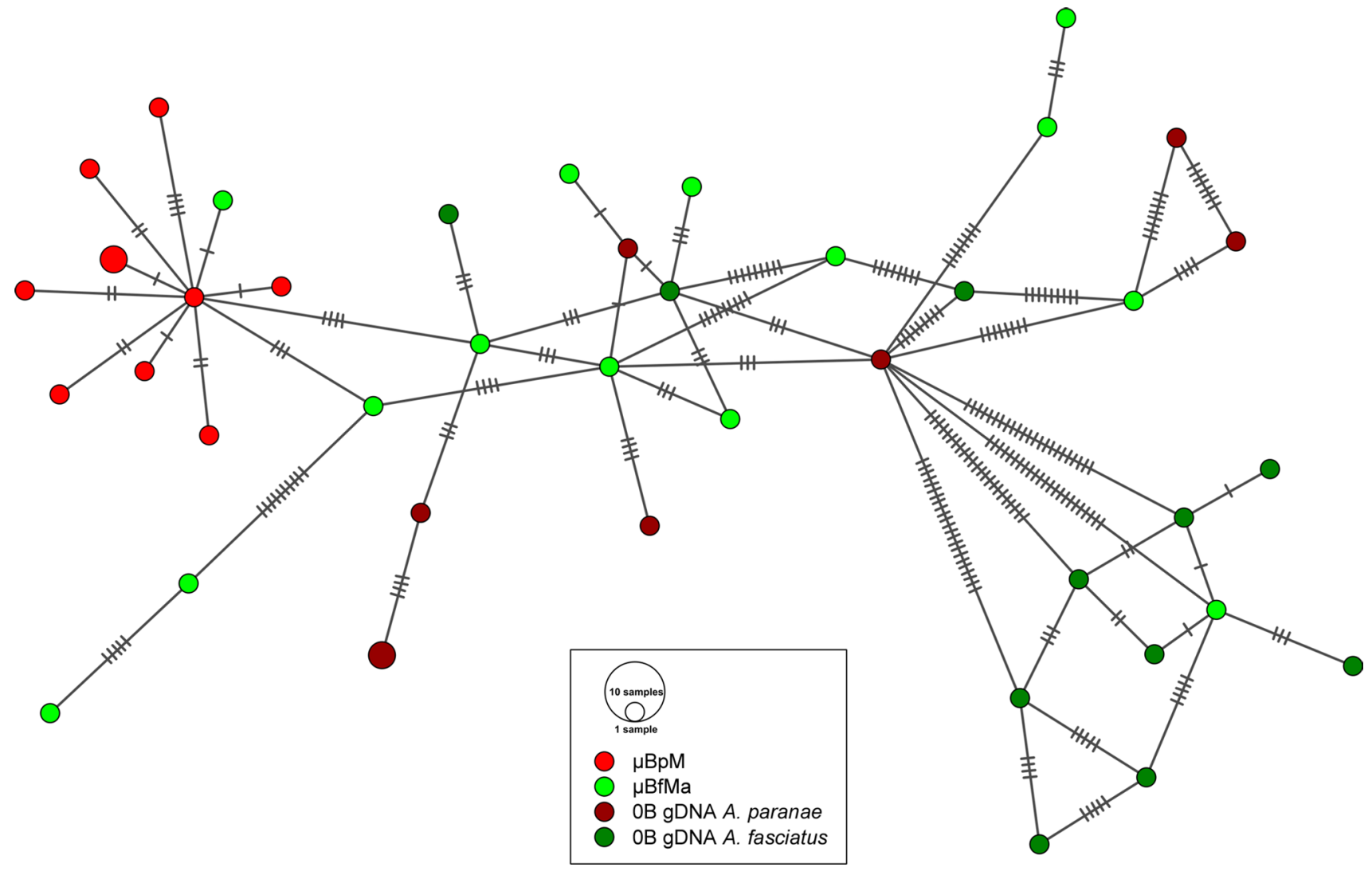

Fig. 5 Minimum Spanning Network showing similarity relationship between partial DNA sequences for Internal Transcribed Spacer (ITS) obtained from the microdissected $\mathrm{B}$ chromosomes (BpM and BfMa), and from A chromosomes of $A$. paranae and A. fasciatus. (0B gDNA)
The crossed lines in each connection indicate mutational steps (substitutions) and circle diameters for each haplotype are proportional to their abundance
Table 4 Nucleotide diversity $(\pi)$ for the DNA sequences analyzed, and Student $(\mathrm{t})$ tests comparing A chromosome (0B-gDNA) and microdissected B chromosome $(\mu \mathrm{B})$ sequences

\begin{tabular}{lllrrrrrrrr}
\hline Gene & Species & Source & $n$ & $S$ & Hap & $\pi$ & SD & $t$ & $d f$ & $P$ \\
\hline ITS1 & A. fasciatus & 0B-gDNA & 11 & 24 & 8 & 0.02284 & 0.00547 & & & \\
& & $\mu$ BfMa & 14 & 39 & 12 & 0.02452 & 0.00542 & $0.7662^{\mathrm{a}}$ & 23 & 0.4513 \\
& \multirow{3}{*}{ A. paranae } & 0B-gDNA & 8 & 21 & 7 & 0.02378 & 0.00493 & $0.3178^{\mathrm{b}}$ & 20 & 0.7539 \\
& & $\mu$ BpM & 10 & 10 & 8 & 0.00560 & 0.00115 & $11.3627^{\mathrm{c}}$ & 16 & 0.0001 \\
ITS2 & \multirow{2}{*}{ A. fasciatus } & 0B-gDNA & 11 & 24 & 9 & 0.02434 & 0.00485 & & & \\
& & $\mu$ BfMa & 14 & 29 & 10 & 0.01906 & 0.00433 & $2.8717^{\mathrm{a}}$ & 23 & 0.0086 \\
& \multirow{3}{*}{ A. paranae } & 0B-gDNA & 8 & 6 & 5 & 0.00600 & 0.00124 & $8.2606^{\mathrm{b}}$ & 20 & 0.0001 \\
& & $\mu$ BpM & 10 & 6 & 5 & 0.00333 & 0.00131 & $4.3981^{\mathrm{c}}$ & 16 & 0.0004 \\
\hline
\end{tabular}

Significant tests are highlighted in italics

$n$ number of sequences, $S$ number of segregating sites, Hap number of haplotypes, $S D$ standard deviation, $d f$ degrees of freedom, $P$ probability

a The Student $t$ tests compared nucleotide diversity values between $\mu$ BfMa and A. fasciatus 0B-gDNA

b The Student $t$ tests compared nucleotide diversity values between A. paranae 0B-gDNA and A. fasciatus OB-gDNA

c The Student $t$ tests compared nucleotide diversity values between $\mu \mathrm{BpM}$ and A. paranae $0 \mathrm{~B}$-gDNA
A. paranae than in 0B-gDNA from A. fasciatus. Likewise, ITS2 nucleotide diversity was about 1.3 times lower in the $\mu$ BfMa-DNA than in the 0B-gDNA of $A$. fasciatus, and that in the $\mu \mathrm{BpM}-\mathrm{DNA}$ was about 1.8 times lower than that in 0B-gDNA of A. paranae, again suggesting higher homogenization of ITS2 sequences in the $\mathrm{B}$ chromosome from $A$. paranae than in that from $A$. fasciatus (Table 4). 


\section{Discussion}

\section{The limits of chromosome painting}

At first sight, our results on intra and cross-species chromosome painting might suggest the common origin of B chromosomes in the three species analyzed because all six B chromosomes analyzed (Bfsm was not analyzed by painting) shared DNA sequences showing homology between them and also with some of the A chromosomes (Fig. 1). However, the anonymous nature of the DNA sequences contained in the painting probes makes the information provided by this technique be of very limited reach in respect to $\mathrm{B}$ chromosome origin. Every painting probe presumably contains a mixture of different DNA sequences. Even being generated by the same procedure, the A. paranae $\mathrm{BpM}$ probe painted more A chromosomes in A. fasciatus than the intra-specific BfMa probe, suggesting higher diversity for repetitive sequences in the $\mathrm{BpM}$ probe (Fig. 1).

All seven $\mathrm{B}$ variants analyzed here shared an abundant presence of the $(\mathrm{AC})_{15}$ microsatellite, and this kind of repetitive sequence, if present in the B-probes, could give positive cross-species painting results even though they could have arisen independently. Likewise, transposable elements (TEs) are probably prevalent in the B probes, and their promiscuity within genomes makes them poor markers for evolutionary events unless their specific sequence is considered. A brilliant example of the use of transposon sequence for investigating the origin of a B chromosome was that of McAllister and Werren (1997). Chromosome painting only gives some indications about homology for a mixture of unknown repetitive DNA sequences. This implies that we can wrongly consider the two given painting signals as evidence for homology. However, they could come into view by hybridization for different repetitive DNAs contained in the same probe or for repetitive sequences that, like microsatellites, could have an independent origin in each B chromosome or for genomic elements, like TEs, which could have reached the $\mathrm{B}$ chromosomes after their origin. For this reason, the information provided by chromosome painting is rather limited, and it should be supplemented with information yielded by other techniques.

\section{Physical mapping of known repetitive DNA families}

To date, several classes of repetitive DNAs have been physically mapped in different Astyanax species, providing important clues about karyotype diversification at intra and inter-specific levels (Kavalco and Moreira-Filho 2003; Kavalco et al. 2011, 2012; Hashimoto et al. 2011; Pansonato-Alves et al. 2013; Silva et al. 2013; Tenório et al. 2013). For instance, the chromosomal location of 5S rDNA and $\mathrm{H} 1$ histone sites is remarkably conserved in different species (Mantovani et al. 2005; Hashimoto et al. 2011). Conversely, 18S rDNA and As51 satellite sites can be extremely variable, even within a single population (Jesus et al. 2003; Kantek et al. 2009; Silva et al. 2013). This variation has been related to ectopic recombination (Vicari et al. 2008) and/or TEs (Silva et al. 2013). All these sites, except 5S rDNA, have been detected on different variants of B chromosomes in Astyanax (Mestriner et al. 2000; Vicari et al. 2008; Silva et al. 2014) and are analyzed here in four new $B$ variants in three species.

In Astyanax, the presence of 18S rRNA genes in B chromosomes was first shown in the BpM chromosome of $A$. paranae, although they were inactive (Silva et al. 2014). Here, we have shown the presence of $18 \mathrm{~S}$ rRNA genes in the BfMa variant of A. fasciatus, and the Ag-NOR technique showed that these genes are active in this species (see Figs. 2, 3). In Teleostei, NOR activity in B chromosomes had only been shown previously in Moenkhausia sanctaefilomenae (Hashimoto et al. 2012).

The metacentric B macro-chromosome is the most common B-type in natural populations of different species of Astyanax (Carvalho et al. 2008). Based on their morphological similarity, Moreira-Filho et al. (2001) suggested a common origin for these $\mathrm{B}$ chromosomes preceding the Astyanax species differentiation. Thus, the occurrence of other morphological variants (e.g., submetacentric, subtelocentric and small acrocentric) could be explained as a result of subsequent rearrangements (Néo et al. 2000; Mestriner et al. 2000; Moreira-Filho et al. 2004; Fernandes and Martins-Santos 2005). Based on the presence of $18 \mathrm{~S}$ rDNA and $\mathrm{H} 1$ histone genes in the BpM chromosome, Silva et al. (2014) noted two A chromosomes (the metacentric no. 2 and the acrocentric no. 23 chromosomes) carrying these repetitive DNAs as possible $\mathrm{B}$ chromosome ancestors in $A$. paranae. In fact, the cross-species chromosome painting presented here showed painting signals in several A chromosomes that were similar in size and shape to these chromosomes in the two other species (see Fig. 1).

However, the joint analysis of the four non-anonymous repetitive DNA sequences, which were found in the B chromosomes analyzed here, were by no means common to all chromosomes (see Figs. 2, 4), thus failing to support the common origin hypothesis, except by invoking a complex series of gains and/or losses of several kinds of repetitive DNA families.

The presence of $18 \mathrm{~S}$ rDNA in only two of the seven B chromosomes analyzed, found in two different species, along with the extensive variation shown by this repetitive DNA for A chromosome locations in Astyanax species (see Kavalco and Moreira-Filho 2003; Mantovani et al. 2005), casts many doubts about the reliability of this marker for inferring B chromosome origin. According to the common origin hypothesis, the presence of $18 \mathrm{~S}$ rDNA in the two B 
chromosomes of Astyanax might be a remnant of the $18 \mathrm{~S}$ rDNA present in the A chromosome ancestor, but it should have been lost from the four other B variants. This could have actually happened during subsequent B evolution, but the possibility that $18 \mathrm{~S}$ rDNA, a repetitive DNA showing high ability for intra-genomic movement (Cabrero and Camacho 2008), reached the BpM and the BfMa after the independent origin of these $\mathrm{B}$ chromosomes appears to be more parsimonious.

The second of the markers analyzed, the As51 satellite DNA, was first isolated in A. scabripinnis, and it was present in the two chromosome arms of its metacentric B chromosome, thus indicating its isochromosome nature (Mestriner et al. 2000). However, the As51 satellite DNA was present only in one of the seven B variants analyzed here (BfMa) and only in one of the two arms of this metacentric chromosome (see Fig. 2), suggesting that it is not an isochromosome, a conclusion also supported by the presence of 18S rDNA in only one arm and the asymmetrical distribution of the $(\mathrm{AC})_{15}$ microsatellite between both $\mathrm{B}$ arms.

We observed the presence of clusters of $(\mathrm{AC})_{15}$ microsatellite sequences in all B-types studied here, especially in the $\mathrm{BpM}, \mathrm{BbM}, \mathrm{BfMb}$ and Bfsm chromosomes. The distal clusters of (AC) ${ }_{15}$ microsatellites on both arms of BpM, $\mathrm{BbM}$ and $\mathrm{BfMb}$ support their isochromosome nature. However, the high abundance of this microsatellite on many A chromosomes in all three species (see Fig. S1) makes it a poorly informative marker, as the B chromosome pattern is a simple reflection of the general pattern observed on A chromosomes. Some microsatellites have been found to be associated with other repetitive sequences (MuñozPajares et al. 2011; Ruiz-Ruano et al. 2015). Accordingly, we observed that the (AC) $)_{15}$ microsatellite was frequently located in the terminal regions of B chromosomes, but only in two cases were they co-located with known repetitive DNA families: with $18 \mathrm{~S}$ rDNA in the BpM chromosome and with As51 in the BfMa chromosome (see Fig. 2).

In high contrast with the three other repetitive non-anonymous sequences analyzed here, the chromosome location of the $\mathrm{H} 1$ histone genes in the A chromosomes of Astyanax species is highly conservative (see Hashimoto et al. 2011). Therefore, it should actually be the most reliable marker for testing the common origin of $\mathrm{B}$ chromosomes in these species. However, only the BpM and the Bfst chromosomes carried $\mathrm{H} 1$ histone genes in a pattern that actually would suggest the possibility of common descent through misdivision, but their common origin in an ancestor species would require the loss of one of the variants in each species. Even at an intraspecific level, it is remarkable that the four B variants analyzed in A. fasciatus only shared the (AC) ${ }_{15}$ microsatellite, whereas only BfMa carried 18S rDNA and AS51, and only Bfst carried H1 histone genes, with the two other variants (Bfsm and BfMb) lacking these markers. The common origin for different B chromosome variants can be best traced back on an intraspecific level, as shown in the grasshopper Eyprepocnemis plorans (López-León et al. 1993; Bakkali et al. 1999). However, in Astyanax, even B chromosomes found in the same species showed few signs of common origin, as inferred from the scarce specific repetitive DNA families shared among them. However, the possibility that frequent differential loss of these families in B chromosomes is obscuring their evolutionary pattern cannot be ruled out and should be an interesting topic for future research.

\section{Analysis of ITS-rDNA sequences present in the BpM and BfMa chromosomes}

The analyses of ITS-rDNA sequences present in the BpM and BfMa chromosomes from A. paranae and A. fasciatus, respectively, revealed that one sequence in BfMa showed high similarity with those in $\mathrm{BpM}$, and that most remaining ITS sequences from BfMa showed intermediate characteristics between those obtained from the B-lacking genomes in both species (see Fig. 5). The higher nucleotide diversity observed in BfMa (see Table 4) might suggest that BpM originated from $\mathrm{BfMa}$, as this would be consistent with an ancestral condition for the heterogeneous BfMa sequences. The BpM chromosome is an isochromosome carrying distal 18S rDNA clusters in both arms (Silva et al. 2014) and can undergo autopairing during meiosis in A. paranae (Silva et al., in preparation), likewise in A. scabripinnis (Mestriner et al. 2000). This could promote rDNA homogenization through unequal crossovers in $\mathrm{BpM}$, but not in BfMa, which carries rDNA only in one arm (see Fig. 2), and would explain the lower nucleotide diversity observed in BpM.

The similarity of all A chromosome ITS sequences in A. paranae (obtained from B-lacking individuals) and their similarity with some $\mathrm{A}$ chromosome sequences from $A$. fasciatus and most BfMa sequences would be consistent with hybridization events between these two species (see Fig. 5), and could be a consequence of their close phylogenetic relatedness (Rossini et al. personal communication). Possible introgression of B chromosomes between closely related species has recently been reported in bees (Tosta et al. 2014). In the fish genus Characidium, however, Pansonato-Alves et al. (2014) suggested a common and unique origin for sex chromosomes but independent origins for B chromosomes in three species, after phylogenetic and chromosome painting analysis. Although a common origin for sex chromosomes in relative species is highly parsimonious, our present results indicate that conclusions based on chromosome painting should be tested at DNA sequence level. 
In conclusion, the seven B chromosome types analyzed in these three Astyanax species did not appear to have a common origin, as inferred from the physical mapping of known repetitive DNA sequences, thus contradicting the chromosome painting results. Therefore, we conclude that this latter technique is not reliable to analyze B chromosome origin and ancestry. Our analysis at sequence level suggests the possible common origin for two B chromosome types in two species (BpM and BfMa) through hybridization. This is an interesting prospect for future research since, if such a hybridization ever occurred, other DNA sequences in the genome of these two species should show evidence of the resulting introgression.

\section{Compliance with ethical standards}

Funding This research was funded by grant from the Fundação de Amparo à Pesquisa do Estado de São Paulo (FAPESP) to DMZA (2011/16825-3), grants from Conselho Nacional de Desenvolvimento Científico e Tecnológico (CNPq) to FF and by Coordenação de Aperfeiçoamento de Pessoal de Nível Superior (CAPES). The funders had no role in the study design, data collection and analysis, decision to publish, or preparation of the manuscript.

Conflict of interest All authors declare that they have no competing interests.

Ethical approval Samples were collected in accordance with Brazilian environmental protection legislation (collection permission MMA/ IBAMA/SISBIO_number 3245), and the procedures for sampling, maintenance and analysis of the samples were performed in compliance with international guidelines for the care and use of animals followed by the Brazilian College of Animal Experimentation (COBEA) and was approved (protocol 405) by the Bioscience Institute/UNESP Ethics Committee on the Use of Animals (CEUA).

\section{References}

Altschul SF, Gish W, Miller W, Myers EW, Lipman DJ (1990) Basic local alignment search tool. J Mol Biol 215:403-410

Artoni RF, Shibatta OA, Gross MC, Schneider CH, Almeida MC et al (2006) Astyanax aff. fasciatus Cuvier, 1819 (Teleostei; Characidae): evidences of a species complex in the upper Rio Tibagi basin (Paraná, Brazil). Neotrop Ichthyol 4:1997-2002

Bakkali M, Cabrero J, López-León MD, Perfectti F, Camacho JPM (1999) The B chromosome polymorphism of the grasshopper Eyprepocnemis plorans in North Africa. I. B variants and frequency. Heredity 83:428-434

Cabrero J, Camacho JPM (2008) Location and expression of ribosomal RNA genes in grasshoppers: abundance of silent and cryptic loci. Chromosome Res 16:595-607

Camacho JPM (2005) B Chromosomes. In: Gregory TR (ed) The evolution of the genome. Elsevier, San Diego, pp 223-286

Carvalho RA, Martins-Santos IC, Dias AL (2008) B chromosomes: an update about their occurrence in freshwater Neotropical fishes (Teleostei). J Fish Biol 72:1907-1932

Castro JP, Moura MO, Moreira-Filho O, Shibatta OA, Santos MH et al (2014) Evidence of incipient speciation in Astyanax scabripinnis species complex (Teleostei: Characidae). Neotrop Ichthyol 12(2):429-438
Castro PC, Moura MO, Moreira-Filho O, Shibatta OA, Santos MH et al (2015) Diversity of the Astyanax scabripinnis species complex (Teleostei, Characidae) in the Atlantic forest, Brazil: species limits and evolutionary inferences. Rev Fish Biol Fisher 25:231-244

Cioffi MB, Kejnovsky E, Bertollo LAC (2011) The chromosomal distribution of microsatellite repeats in the genome of the wolf fish Hoplias malabaricus, focusing on the sex chromosomes. Cytogenet Genome Res 132:289-296

Daniel SN, Hashimoto DT, Pansonato-Alves JC, Foresti F, Porto-Foresti F (2012) Cytogenetic characterization of distinct B chromosomes in a population of the fish Astyanax bockmanni (Teleostei, Characiformes). Caryologia 65(3):228-233

Daniel SN, Penitente M, Hashimoto DT, Silva DMZA, Foresti F, Porto-Foresti F (2015) New insights into karyotypic relationships among populations of Astyanax bockmanni (Teleostei, Characiformes) of different watersheds. Zebrafish 12(2):181-188

Eschmeyer WN Catalog of fishes. California Academy of Sciences, electronic version http://www.calacademy.org/scientists/projects/ catalog-of-fishes. Accessed date 15 Dec 2015

Fernandes CA, Martins-Santos IC (2005) Sympatric occurrence of three cytotypes and four morphological types of B chromosomes of Astyanax scabripinnis (Pisces, Characiformes) in the river Ivaí Basin, state of Paraná, Brazil. Genetica 124:301-306

Foresti F, Toledo-Filho AS, Almeida-Toledo LF (1981) Polymorphic nature of the nucleolus organizer regions in fishes. Cytogenet Cell Genet 31:134-141

Gribble S, Ng BL, Prigmore E, Burford DC, Carter NP (2004) Chromosome paints from single copies of chromosomes. Chromosom Res 12:143-151

Hashimoto DT, Gonçalves VR, Bortolozzi J, Foresti F, Porto-Foresti F (2008) First report of a B chromosome in a natural population of Astyanax altiparanae (Characiformes, Characidae). Genet Mol Biol 31:275-278

Hashimoto DT, Ferguson-Smith MA, Rens W, Foresti F, Porto-Foresti F (2011) Chromosome mapping of H1 histone and 5S RNA gene clusters in three species of Astyanax (Teleostei: Characiformes). Cytogenet Genome Res 134:64-71

Hashimoto DT, Voltolin TA, Paes ADNVA, Foresti F, Bortolozzi J et al (2012) Cytogenetic analysis of B chromosomes in one population of the fish Moenkhausia sanctaefilomenae (Steindachner, 1907) (Teleostei, Characiformes). Comp Cytogenet 6(2):141-151

Houben A, Banaei-Moghaddam AM, Klemme S, Timmis JN (2013) Evolution and biology of supernumerary B chromosomes. Cell Mol Life Sci 71(3):467-478

Howell WM, Black DA (1980) Controlled silver staining of nucleolus organizer regions with a protective colloidal developer: a 1-step method. Experientia 36:1014-1015

Jesus CM, Galetti PM, Valentini SR, Moreira-Filho O (2003) Molecular characterization and chromosomal localization of two families of satellite DNA in Prochilodus lineatus (Pisces, Prochilodontidae), a species with B chromosomes. Genetica 118(1):25-32

Kantek DLZ, Vicari MR, Peres WAM, Cestari MM, Artoni RF et al (2009) Chromosomal location and distribution of As51 satellite DNA in five species of the genus Astyanax (Teleostei, Characidae, Incertae sedis). J Fish Biol 75:408-421

Katoh K, Standley DM (2013) MAFFT multiple sequence alignment software version 7: improvements in performance and usability. Mol Biol Evol 30(4):772-780

Kavalco KF, Moreira-Filho O (2003) Cytogenetical analyses in four species of the genus Astyanax (Pisces, Characidae) from Paraíba do Sul river basin. Caryologia 56:453-461

Kavalco KF, Brandão KO, Garcia C, Pazza R, Almeida-Toledo LF (2011) Comparative cytogenetics and molecular phylogeography 
in the group Astyanax altiparanae-Astyanax aff. bimaculatus (Teleostei, Characidae). Cytogenet Genome Res 134(2):108-119

Kavalco KF, Pazza R, Brandão KO, Almeida-Toledo LF (2012) Biogeographic patterns in the chromosomal distribution of a satellite DNA in the banded tetra Astyanax fasciatus (Teleostei: characiformes). Org Divers Evol 13(1):67-76

Klemme S, Banaei-Moghaddam AM, Macas J, Wicker T, Novák P et al (2013) High-copy sequences reveal distinct evolution of the rye B chromosome. New Phytol 199:550-558

Levan A, Fredga K, Sandberg AA (1964) Nomenclature for centromeric position of chromosomes. Hereditas 52:201-220

Librado P, Rozas J (2009) DnaSP v5: a software for comprehensive analysis of DNA polymorphism data. Bioinformatics 25:1451-1452

López-León MD, Cabrero J, Pardo MC, Viseras E, Camacho JPM, Santos JL (1993) Generating high variability of B chromosomes in the grasshopper Eyprepocnemis plorans. Heredity 71:352-362

Mantovani M, Abel LDDS, Moreira-Filho O (2005) Conserved 5S and variable $45 \mathrm{~S}$ rDNA chromosomal localisation revealed by FISH in Astyanax scabripinnis (Pisces, Characidae). Genetica 123(3):211-216

Martis MM, Klemme S, Banaei-Moghaddam AM, Blattner FR, Macas J et al (2012) Selfish supernumerary chromosome reveals its origin as a mosaic of host genome and organellar sequences. Proc Natl Acad Sci 109(33):13343-13346

McAllister BF, Werren JH (1997) Hybrid origin of a B chromosome (PSR) in the parasitic wasp Nasonia vitripennis. Chromosoma 106:243-253

Mestriner CA, Galetti PM Jr, Valenttini SR, Ruiz IRG, Abel LDS et al (2000) Structural and functional evidence that a B chromosome in the characid fish Astyanax scabripinnis is an isochromosome. Heredity 85:1-9

Montoya-Burgos JI (2003) Historical biogeography of the catfish genus Hypostomus (Siluriformes: Loricariidae), with implications on the diversification of Neotropical ichthyofauna. Mol Ecol 12:1855-1867

Moreira-Filho O, Bertollo LCA (1991) Astyanax scabripinnis (Pisces, Characidae). A species complex. Braz J Genet 14:331-357

Moreira-Filho O, Fenocchio AS, Pastori MC, Bertollo LAC (2001) Occurrence of a metacentric macrochromosome B in different species of the genus Astyanax (Pisces, Characidae, Tetragonopterinae). Cytologia 66:59-64

Moreira-Filho O, Galetti PM Jr, Bertollo LAC (2004) B chromosomes in the fish Astyanax scabripinnis (Characidae, Tetragonopterinae). An overview in natural populations. Cytogenet Genome Res 106:230-234

Muñoz-Pajares AJ, Martínez Rodriguez L, Teruel M, Cabrero J, Camacho JPM, Perfectti F (2011) A single, recent origin of the accessory B chromosome of the grasshopper Eyprepocnemis plorans. Genetics 187:853-863

Néo DM, Bertollo LAC, Moreira-Filho O (2000) Morphological differentiation and possible origin of $\mathrm{B}$ chromosomes in natural Brazilian populations of Astyanax scabripinnis (Pisces, Characidae). Genetica 108:211-215

Oliveira C, Foresti F, Hilsdorf AWS (2009) Genetics of Neotropical fish: from chromosomes to populations. Fish Physiol Biochemist 35:81-100

Ornelas-García CP, Domínguez-Domínguez O, Doadrio I (2008) Evolutionary history of the fish genus Astyanax Baird \& Girard (1854) (Actinopterygii, Characidae) in Mesoamerica reveals multiple morphological homoplasies. BMC Evol Biol 8:340

Pansonato-Alves JC, Hilsdorf AWS, Utsunomia R, Silva DMZA, Oliveira C et al (2013) Chromosomal mapping of repetitive DNA and cytochrome $\mathrm{C}$ oxidase I sequence analysis reveal differentiation among sympatric samples of Astyanax fasciatus (Characiformes, Characidae). Cytogenet Genome Res 141(2-3):133-142

Pansonato-Alves JC, Serrano EA, Utsunomia R, Camacho JPM, Costa-Silva GJ et al (2014) Single origin of sex chromosomes and multiple origins of B chromosomes in fish genus Characidium. PLoS One 9(9):e107169

Pazza R, Kavalco KF, Bertollo LAC (2006) Chromosome polymorphism in Astyanax fasciatus (Teleostei, Characidae). 1. Karyotypic analysis, Ag-NORs and mapping of the $18 \mathrm{~S}$ and $5 \mathrm{~S}$ ribosomal genes in sympatric karyotypes and their possible hybrid forms. Cytogenet Genome Res 112:313-319

Pazza R, Kavalco SAF, Penteados PR, Kavalco KF, Almeida-Toledo LF (2008) The species complex Astyanax fasciatus Cuvier (Teleostei, Characiformes) — a multidisciplinary approach. J Fish Biol 72:2002-2010

Perfectti F, Werren JH (2001) The interspecific origin of B chromosome: experimental evidence. Evolution 55(5):1069-1073

Pinkel D, Straume T, Gray JW (1986) Cytogenetic analysis using quantitative, high sensitivity, fluorescence hybridization. Proc Natl Acad Sci 83:2934-2938

Ruiz-Ruano FJ, Cuadrado Á, Montiel EE, Camacho JPM, LópezLeón MD (2015) Next generation sequencing and FISH reveal uneven and nonrandom microsatellite distribution in two grasshopper genomes. Chromosoma 124(2):221-234

Santos LPD, Castro JP, Francisco CMD, Vicari MR, Almeida MCD et al (2013) Cytogenetic analysis in the neotropical fish Astyanax goyacensis Eigenmann, 1908 (Characidae, incertae sedis): karyotype description and occurrence of B microchromosomes. Mol Cytogenet 6(1):1-10

Silva DMZA, Pansonato-Alves JC, Utsunomia R, Daniel SN, Hashimoto DT et al (2013) Chromosomal organization of repetitive DNA sequences in Astyanax bockmanni (Teleostei, Characiformes): dispersive location, association and co-localization in the genome. Genetica 141:329-336

Silva DMZA, Pansonato-Alves JC, Utsunomia R, Araya-Jaime C, RuizRuano FJ et al (2014) Delimiting the origin of a B chromosome by Fish mapping, chromosome painting and DNA sequence analysis in Astyanax paranae (Teleostei, Characiformes). PLoS One 9:e94896

Tenório RCCO, Vitorino CA, Souza IL, Oliveira C, Venere PC (2013) Comparative cytogenetics in Astyanax (Characiformes: Characidae) with focus on the cytotaxonomy of the group. Neotrop Ichthyol 11(3):553-564

Tosta VC, Marthe JB, Tavares MG, Fernandes-Salomão TM, Pompolo SG et al (2014) Possible introgression of B chromosomes between bee species (genus Partamona). Cytogenet Genome Res 144(3):220-226

Trifonov VA, Dementyeva PV, Larkin DM, O’Brien PCM, Perelman PL et al (2013) Transcription of a protein-coding gene on B chromosomes of the Siberian roe deer (Capreolus pygargus). BMC Biol 11:90

Utsunomia R, Silva DMZA, Ruiz-Ruano FJ, Araya-Jaime C, Pansonato-Alves JC et al (2016) Uncovering the ancestry of B chromosomes in Moenkhausia sanctaefilomenae (Teleostei, Characidae). PLoS ONE 11(3):e0150573

Valente GT, Conte MA, Fantinatti BE, Cabral-de-Mello DC, Carvalho RF et al (2014) Origin and evolution of B chromosomes in the Cichlid Fish Astatotilapia latifasciata based on integrated genomic analyses. Mol Biol Evol 31(8):2061-2072

Vicari MR, Artoni RF, Moreira-Filho O, Bertollo LAC (2008) Colocalization of repetitive DNAs and silencing of major rRNA genes. A case report of the fish Astyanax janeiroensis. Cytogenet Genome Res 122:67-72

Vicari MR, Pistune HFM, Castro JP, Almeida MC, Bertollo LAC et al (2011) New insights on the origin of B chromosomes in Astyanax scabripinnis obtained by chromosome painting and fish. Genetica 139:1073-1081

Vicente VE, Moreira-Filho O, Camacho JPM (1996) Sex-ratio distortion associated with the presence of a B chromosome in Astyanax scabripinnis (Teleostei, Characidae). Cytogenet Cell Genet 74:70-75 